\title{
Gram Panchayat Schemes and rural women
}

\author{
SUMAN M. PUJAR* AND UMA S. HIREMATH \\ Department of Extension and Communication Management, College of Rural Home Science, University \\ of Agricultural Science, DHARWAD (KARNATAKA) INDIA \\ (Email : pujarsuman8@gmail.com, hiremathuma57@gmail.com )
}

\begin{abstract}
Panchayat Raj Institutions (PRIs) become an effective mechanism to achieve equitable rural development. The schemes and programmes lay primary emphasis on the development of human beings. It involves a spectrum of behavioural aspects ranging from perception of the target groups to social norms, values, beliefs and roles. Hence, the study was under taken to know the knowledge level, problems faced by the women beneficiaries and suggestive measures for effective implementation about housing, employment and pension schemes. The data was collected from 360 women beneficiaries selected from four villages of Uppin-Betageri Gram panchayat of Dharwad taluka of Dharwad district. The overall knowledge level of women beneficiaries about housing schemes was high (46.25\%), medium (48.50\%) in pension and low (46.25\%) in employment schemes. More number of women beneficiaries had problems in housing scheme (36.25\%) followed by pension (26.00\%) and employment schemes $(21.25 \%)$. About sixty seven per cent of women beneficiaries gave suggestions in housing scheme (67.50\%) followed by pension $(57.50 \%)$ and employment schemes $(48.75 \%)$.
\end{abstract}

KEY WorDS : Gram Panchayat, Schemes, Rural women

View Point Article : Pujar, Suman M. and Hiremath, Uma S. (2014). Gram Panchayat Schemes and rural women. Internat. J. Home. Sci. Extn. \& Comm. Mgmt., 1 (2): 106-110.

Article History : Received : 16.12.2013; Revised : 01.06.2014; Accepted : 12.06.2014

\footnotetext{
* Author for correspondence
} 